\title{
INDIAN RETAIL INVESTORS AND INITIAL PUBLIC OFFERS: PRE AND POST COVID ANALYSIS
}

\author{
Sreyansh Surana \\ Masters Student at Symbiosis Institute of Business Management \\ 95/1 Electronic City Phase 1, Hosur Road, Bengaluru-560100, Karnataka India \\ Email-sreyansh.surana21@sibm.edu.in
}

\begin{abstract}
Going public is one of the most popular forms of raising funds for expansion and growth of business. Since the liberalisation of economy in 1991, more than 1500 companies have listed themselves on the exchange. And the Indian stock markets keep expanding with increasing number of public offers in both mainstream and SME category. This paper compares the IPOs of Indian markets in broadly two phases-pre covid and post covid. A sample of 242 listings across eleven years from 2010-2020 are considered for the study. A comparison based on details of listing, listing gains etc reveal a more active retail investor segment. Overoptimism and urge to synthesise short term gains contribute to such gains. This is further backed by analysis of search results in the Indian region using google trends. Tail events such as covid-19 alter the way Indian investors behave and invest in IPOs and make their investments more on basis of speculative measures such as grey market premium, than actual fundamentals of the issue under consideration.
\end{abstract}

Keywords: Initial Public Offers, Retail Individual Investors, Listing Gains, Google Trends, Grey Market Premium

\section{Introduction}

As of December 2020, there are around 1913 companies listed on the national stock exchange of India. Out of these around 1790 are actively traded. Equity market capitalization was INR 6.12 Trillion in 2001-02 and was 203 trillion in 2020-21 (BSE (Formerly Bombay Stock Exchange) | Market Watch Download, n.d.). It has grown at a CAGR of around $20 \%$. In the last decade Indian stock markets have witnessed approximately 200 Initial Public Offerings (IPOs). An IPO is a process by which a private company raises capital from the public for the first time by offering equity shares. Participants in IPOs include Retail Individuals Investors (RIIs), Qualified Institutional Buyers (QIBs), Non-Institutional Investors (NIIs), High Net Worth Investors (HNIs) etc. The purpose of raising funds range from expansion, diversification, working capital financing, CDR (Corporate Debt restructuring), financing assets etc.
Resident Indian nationals who invest up to two lakhs in an issue are categorised as RIIs. A minimum of thirty-five percent of the issue size is reserved for them. Resident Indian nationals who apply for more than two lakhs in an issue and HNIs and a minimum of fifteen percent of the issue size is reserved for them. Foreign Portfolio investors, mutual funds, commercial banks, public financial institutions etc are categorised as QIB investors. Fifty percent of the issue size is reserved of them.

\section{Objectives}

This paper aims at studying the investor behaviour with respect to IPOs in the Indian capital markets post and pre covid-19 times. All IPO issues which were successful, from the year 2010 till February $3^{\text {rd }}, 2021$, have been considered as data set for the study. To draw a clear line between pre-covid and post-covid times 16th March 2020 has been selected as the cut-off date. This implies all initial public offers post as on $16^{\text {th }}$ March 2020 and after are post covid IPOs and till $15^{\text {th }}$ March 2020 are pre-covid IPOs.

\section{Literature Review}

Studying investor behaviour in and around tail events such as a pandemic like covid-19 becomes extremely essential. In fact, it is more important than studying financial markets around events which are non-tail. Historically, it is the tail events which have had a greater impact on market returns than any other. Be it the oil crisis of 1970s, financial crisis of 2008 or the recent pandemic. Such events often bring a paradigm shift in the way the world behaves.

(Ndirangu et al., 2014) study the individual investor behavior during IPOs in Kenyan equity markets. Their findings reveal critical aspects of investor behavior around IPOs such as despite trivial listing gains and majority of the retail investors there being short term investors, there is tremendous market rush around IPOs. The recent rise in access to internet can also be attributed as a cause in the increase in number of investors. Also, more investors now feel more informed because they have access to internet. In light of these findings, Indian investors form a good subject of study. India is a developing economy and witnessed a record shattering growth in number 
of internet users in the last decade. (Ndirangu et al., 2014) surveyed investors at the Nairobi stock exchange. Their study is descriptive and sentiment based. This paper on the contrast seeks to extract meaningful information from the numbers around the public offers pertaining to the abovementioned period.

(Bhattacharjee \& Das, 2020) study the impact of the pandemic on Indian capital markets by scrutinizing the trends of eight prominent indices, behavior of FIIs and DIIs, developments in the Indian primary market and the reaction of regulators thereby. As per their findings, March 2020 witnessed major sell off on FII end and the market overall moved towards bear territory.

(Wu et al., 2020) Investigate the Chinese stock markets during pandemic for traces of herding behavior and find it to be significantly lower during covid times as compared to usual. This implies that Chinese investors become more skeptical and cautious with respect to financial markets during times of crisis. It becomes an imperative to study how Indian investors behave in covid like circumstances.

(Ali et al., 2020) study how global markets respond in epidemic (pre covid for this paper) and pandemic (covid and after) phases and find that the Chinese markets relatively were calmer and exhibited lesser volatility contrary to that of US, UK, Germany and South Korea. A period of thirty days in the pandemic witnessed around thirty percent wealth deterioration globally. The non-Chinese markets were characterized by panic buying-selling and higher levels of volatility thereby. This paper doesn't attempt to study the Indian markets in same light. It narrows down the focus to a specific area-IPO.

(Poornima, 2016) find that IPOs are majorly a speculative tool in India for Indian investors based on studying nine companies between January 2013 and December 2014. This paper intends to uncover new findings in a similar direction and by studying a larger sample size. (Sahoo \& Rajib, 2010) study details of 92 IPOs in India between 2002-2006 and find on average IPOs are under-priced by approximately $47 \%$. Such under-pricing trend has whether been challenged by the pandemic of covid19 or not is the subject of this research. (Ibbotson \& Ritter, 1995) document three primary anomalies for IPOs across a lot of countries as i) new issues being under-priced, ii) cyclical trends in volumes of trading, iii) long run underperformance of IPOs. The authors find no one model captures all these anomalies into one and conclude that collectively these three account for a great number of patterns seen in IPO data. (Singh, 2012) finds that offer documents of issues influence returns across sectors and both long and short term. The study, however, pertains to a period not marked by a covid like event. In such a case, how covid altered the behaviour of Indian investors becomes an essential area to study.

(Sethi et al., 2020) use machine learning approach to break down discussion via comments on message boards and find that common topics of discussion include financial statement analysis, investment advice, industry performance, etc. These pertain more to the investors who assume the long-term vision of investing. A short-term investor would rather not discuss about such areas and focus more on listing gains. Also, the percentage population of people commenting, influences the reliability of investor behavior results obtained. One significant take away is that decoding investor behavior around IPOs could be significant. However, this should not be studied in isolation. Factors such as unemployment, liquidity, repo rates prevailing in the economy need to be studied jointly. (Ding et al., 2020) analyze sector wise daily stock returns jointly with market sentiment and establish that market sentiment during covid times did affect stock market returns across sectors especially the ones leveraging greatly on digital transformation. More digitally transformed sectors outperformed the lesser ones. What's interesting is the researchers used search results to model market sentiment. This paper borrows insights from the same tool used by (Ding et al., 2020) i.e. google trends to corroborate investor sentiment around IPOs.

(Loughran et al., 1994) present evidence that companies time their IPOs around periods when valuations are high with investors reaping low returns in the long term. What's crucial to note here is to find evidence if companies which already timed their offers increase their issue size when market is overvalued or during times of high liquidity. This paper attempts to ignite a spark in this direction.

(Pollock \& Rindova, 2003) find that publicly available information as provided by various media houses impact investor behavior in association to an IPO and thereby listing gains. In the 225 issues studied, it was found that volume of media information positively impacted investor response. Investors believing in such information is caused by two factors. One is the information availability which was studied by the paper mentioned here. The other is the extent of reliability the investor places on such information due to the external environment and changing economic scenarios. An event such as pandemic varies this factor and might cause investors to place more reliance on available information. This over reliance is caused by over optimism or simply ignorance.

(Cornelli et al., 2006) use grey market prices of European IPOs and find evidence of a link between sentiment of small investors and post listing prices. Small investors if driven by overoptimism cause listing prices to shoot up and vice versa. The interesting question one may ask is what if the investors are not driven by either of overoptimism or pessimism but pure irrationality and in context of a developing country like India with comparatively higher levels of unemployment, people may resort to stock market investing as alternative to finding a job. Contributions of (Cornelli et al., 2006) to the existing literature in IPO related studies are significant in terms of studying grey market premium and investor sentiment. 
(Manu \& Saini, 2020) study the IPOs in India in the year 2017 using event study methodology and find that around seventy percent of the IPOs were underpriced in the short run. This however is expected to change in the pandemic and would be the subject of this paper. The study also identified various factors that influence the movement of IPOs in the short run and conclude that the short run performances of such IPOs are not impacted by age of company, issue size of the IPO, ownership sector and promoters' holdings. One must think what if the issue size itself is a dependent variable influence by companies attempting to exploit market sentiment when they can?

\section{Methodology}

IPO listing data from 2010 to $3^{\text {rd }}$ February 2021 has been collected from moneycontrol.com. The dataset has parameters such as overall times subscribed with breakup for QIBs, HNIs and RIIs, listing gains, current market price (as on February $24^{\text {th }}, 2021$ ), and gains from listing till February $24^{\text {th }}, 2021$. This data has been simply analyzed using descriptive statistics and measures of central tendency.

\section{Findings}

Listing gains here mean the maximum return an investor could have generated based on the prices on the date the stock started first trading on the exchange. Descriptive statistics of Percentage of Listing Gains reveal that in covid and ahead times listing gains are far higher than in pre-covid times. Mean (41.04 vs -0.96) and median (19.31 vs 0.03 ) both are on higher for post covid times. This can be attributed to the overoptimism of investors. Since we have entire population (i.e., all IPOs in Indian markets in Post covid and Pre covid times) standard error doesn't make sense. While standard deviation is more in Post covid times, the higher negative minimum leads to an average negative listing gain for pre covid times. It means the downside was heavier before the pandemic and on average people were not over optimistic.

\begin{tabular}{|l|l|l|l|}
\hline & Particulars & $\begin{array}{l}\text { Covid and } \\
\text { ahead }\end{array}$ & Pre Covid \\
\hline \multirow{4}{*}{$\begin{array}{l}\text { Listing } \\
\text { Gains } \%\end{array}$} & Mean & 41.04 & -0.96 \\
\cline { 2 - 4 } & $\begin{array}{l}\text { Standard } \\
\text { Deviation }\end{array}$ & 49.76 & 43.93 \\
\cline { 2 - 4 } & Count & 19 & 223 \\
\cline { 2 - 4 } & Standard Error & 11.41 & 2.94 \\
\cline { 2 - 4 } & Median & 19.31 & 0.03 \\
\cline { 2 - 4 } & Minimum & -13.97 & -97.15 \\
\cline { 2 - 4 } & Maximum & 130.67 & 153.5 \\
\hline
\end{tabular}

Table 1 Descriptive Statistics of Listing Gains (Source: researcher's calculations)

Issue size here means how much capital in Indian national Rupees was sought by the issues under consideration here.
Descriptive statistics of Issue size reveal that on average issue size has increase during covid and post covid. Mean issue size in covid and ahead is 1785 Crores and in pre-covid it was 830 (approx.) making it nearly 2.2 times. Median issue size in post covid is 600 and in pre-covid it was 115 making it nearly 5.2 times. This shows companies too saw opportunity in the pandemic when investors were showing traits of overoptimism. On average they raised more capital than companies which raised in pre-covid times. This is surprising as economic activity was slowing down, lay-offs were increasing and a lot of companies filed for bankruptcy or shut down operations (either temporarily or permanently). By this time the reserve bank of India had, through a series of rate cuts, brought down the repo rate close to 4\% (Reserve Bank of India - Handbook of Statistics on Indian Economy, n.d.). Banks have reduced savings account interest rates close to $3 \%$ $3.5 \%$. Fixed deposit rates range between 4\%-7\%. Anything above this is lucrative enough for investors to chase. Let's assume a family of investors applied for all IPOs in the Post covid times. And they were allotted almost all IPOs. This would generate for them an average of $42 \%$ returns assuming they simply targeted listing gains. The minimum issue size is higher for post-covid and the maximum issue size is lower. This shows that the post covid data issue size mean isn't boosted because of a few high-volume issues.

\begin{tabular}{|l|l|l|l|}
\hline & Particulars & $\begin{array}{l}\text { Covid and } \\
\text { ahead }\end{array}$ & Pre Covid \\
\hline \multirow{3}{*}{$\begin{array}{l}\text { Issue Size } \\
\text { (Crs) }\end{array}$} & Mean & 1785.06 & 829.23 \\
\cline { 2 - 4 } & $\begin{array}{l}\text { Standard } \\
\text { Deviation }\end{array}$ & 2628.18 & 1709.89 \\
\cline { 2 - 4 } & Count & 19 & 223 \\
\cline { 2 - 4 } & Standard Error & 602.95 & 114.50 \\
\cline { 2 - 4 } & Median & 600 & 358.16 \\
\cline { 2 - 4 } & Minimum & 61.2 & 0 \\
\cline { 2 - 4 } & Maximum & 10286.2 & 15475 \\
\hline
\end{tabular}

Table 2 Descriptive Statistics of Issue Size (Source: researcher's calculations)

Current returns mean the returns on the stocks from listing date to date of data extraction (24 $4^{\text {th }}$ February 2021 in this case). Descriptive statistics for current gains might present a slightly absurd picture but is essential here to give a direction for future analysis. For post covid the current gains are far higher than pre covid mean gains. This however is natural. The pre covid data covers a longer period of time and a larger sample of companies. Over a longer period of time stocks get more room to correct prices and align closer to their fundamentals and move more. Which is why standard deviation of pre covid data is higher. Stocks have moved more with some generating returns as high as $2043 \%$ and some generating losses of around nearly $100 \%$. On either side it is far greater than the post covid period returns. Given more time 
we'd be able to track the returns of pre covid IPOs vis-à-vis post covid stocks. This would help us understand up to what extent the post covid returns were boosted by normal factors affecting pre covid stocks as well and up to what extent were, they boosted by pandemic specific overoptimism of retail investors.

\begin{tabular}{|c|c|c|c|}
\hline & Particulars & $\begin{array}{l}\text { Covid and } \\
\text { ahead }\end{array}$ & Pre Covid \\
\hline \multirow{7}{*}{$\begin{array}{l}\text { Current } \\
\text { Gains \% }\end{array}$} & Mean & 76.17 & 22.37 \\
\hline & $\begin{array}{l}\text { Standard } \\
\text { Deviation }\end{array}$ & 95.90 & 215.11 \\
\hline & Count & 19 & 223 \\
\hline & $\begin{array}{l}\text { Standard } \\
\text { Error }\end{array}$ & 22.00 & 14.4 \\
\hline & Median & 42.88 & -36.75 \\
\hline & Minimum & -4.04 & -99.93 \\
\hline & Maximum & 386.29 & 2043.21 \\
\hline
\end{tabular}

Table 3 Descriptive Statistics of Current Gains (Source: researcher's calculations)

One might wonder an event such as a global pandemic should have rendered investors, especially retail ones more pessimistic than optimistic. But what this paper proposes is contrary. And there can be reasonable grounds to say so. While businesses were shut, layoffs increased people started looking for alternative sources of income. Although some resorted to supplying essentials during the pandemic such as food, medicine, medical equipment, etc., a good majority also considered resorting to trading in stocks and commodities. Even during the lockdown, the markets were open and buying and selling of securities was permitted. This can be further corroborated by the fact that that in year 2020 India witnessed the highest ever youth unemployment rate at $23.75 \%$ (Figure 1). Data for the same collected from Statista (India - Youth Unemployment Rate 1999-2020, n.d.).

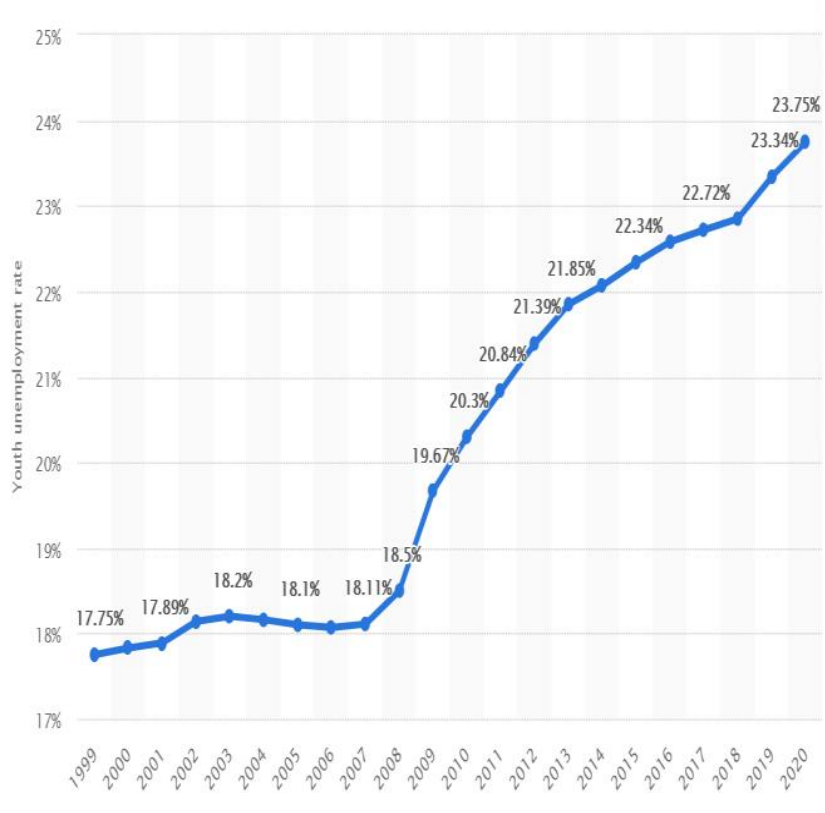

Figure 1 Youth Unemployment over the years in India (Source- Statista)

To further support the fact that Indian IPO markets in post covid times were driven by an urge for short term sources for alternate income generation let us use a tool which recently gained prominence and has been used in multiple researches. (Ding et al., 2020) uses (Google Trends, n.d.) to analyze investor sentiment around IPOs. The google trends helps us chart how many times the phrase "grey market premium" was searched on google in a specific region and within a specified time interval. Grey market premium means how much the investors are willing to pay for the shares before the allotment on a 'when issued" basis. Let's say Mr. X and Mr. Y both apply for an issue. However only $\mathrm{Y}$ is allotted the shares. $\mathrm{Mr}$. $\mathrm{X}$ for some reason believes the share prices would go up tremendously and is therefore ready to pay a certain premium on the issue price. He offers Mr. Y a deal at $50 \%$ premium and $\mathrm{Y}$ agrees to sell him the shares. This extra $50 \%$ which $\mathrm{X}$ is ready to pay is grey market premium. Often this is determined as part of the book building process. It only gets close to possible listing gains post allotment and close to listing date. We can see in Figure 2 How many times grey market premium was searched in google in India between $2^{\text {nd }}$ march 2010 and $3^{\text {rd }}$ march 2021 . We can clearly note the surge in the search of this phrase in the recent pandemic. This is the highest surge in the last decade. Inferring from this we can say more and more people searched this phrase on google because they were more concerned about an issue generating enough listing gains for them instead of the long-term potentials of the company. 
grey market premium

Search term

India v 2/3/10-3/3/21 " All categories " Web Search v

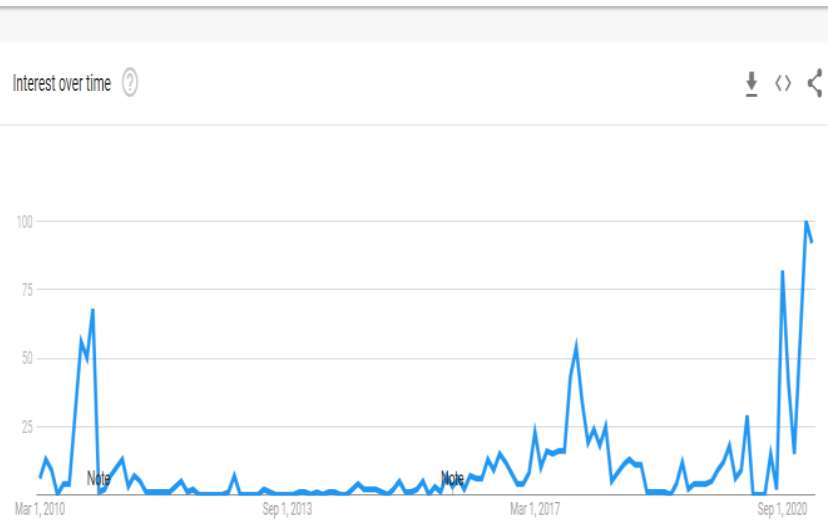

Figure 2 Grey Market Premium Search statistics as per Google Trends

That not alone. A look into some other key words helps us further understand the issue better. We can see in figure 3 the term IPO also gained search prominence in post covid times and the word Zerodha gained higher searches too. Zerodha is an emerging and well performing Stock trading platform amongst Indian investors. One of the reasons its gaining popularity is its low-cost services of around INR 200 (roughly 2.6 USD) per annum for trading in equity and the ease it allows to apply for securities in IPOs. One can do it over cell phones and hand-held devices and pay using UPI (Unified Payments Interface) apps such as Google's own G-pay, and respective UPI of banks.
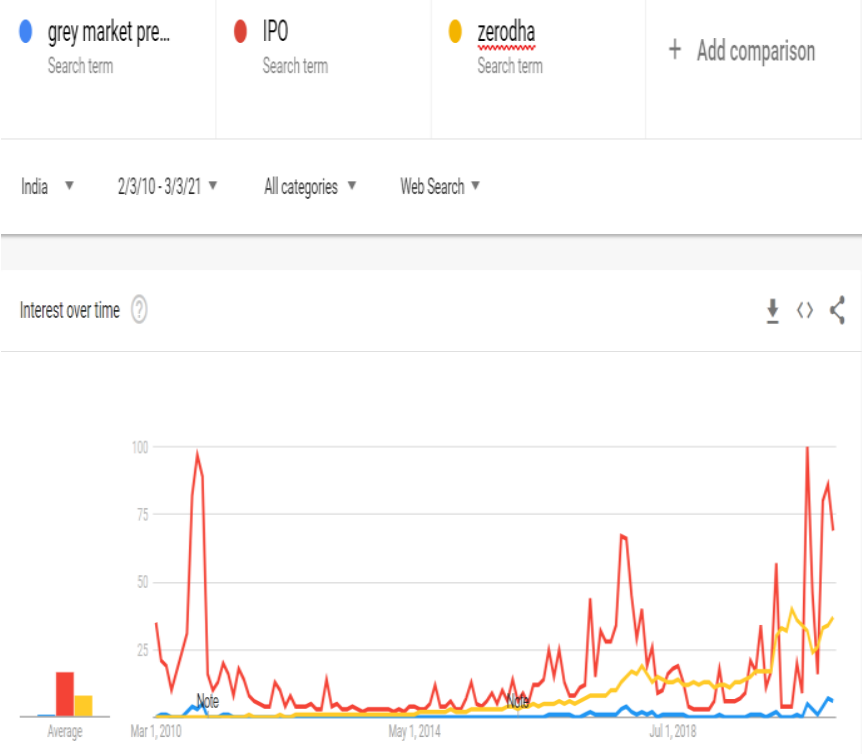

Figure 3 Grey Market Premium, IPO, Zerodha Search statistics as per Google Trends
For instance, there are ten applications for every lot of shares. The times subscribed is 10 . It means there are ten investors chasing every one lot of shares. The sum of all the 'time subscribed' of all IPOs in a year when divided by number of IPOs in that year give 'average times subscribed.' Let's analyze the category wise "average times subscribed" for both post covid and pre covid.

\begin{tabular}{|l|l|l|l|}
\hline Category & Pre Covid & Post Covid & \%change \\
\hline QIB & 20.93 & 50.879 & $143 \%$ \\
\hline HNI & 61.32 & 157.94 & $158 \%$ \\
\hline RII & 6.29 & 18.37 & $192 \%$ \\
\hline
\end{tabular}

Table 4 Category Wise Change in Average Times Subscribed across Pre and Post Covid Times (Source- researcher's calculations)

For all IPOs in post covid and pre covid, "times subscribed" for the separate categories of investors were taken and their mean was obtained. It could be ascertained that all the three categories -QIB, HNI, and RII witnessed significant increase however RII or the Retail Segment witnessed the highest increase in times subscribed i.e., 192\%. This again shows how retail investors in India became more active during and post pandemic.

Sum of all listing gains provided by all the IPOs in a given year when divided by the number of IPOs give us the average listing gains. Such average when plotted on a graph reveal that post pandemic witnessed highest average listing gains per IPO. Year 2021 data past completion of the year would further give a clear picture. Figure 4 below shows the average listings gains per IPO over the years. This further goes on to show how the pandemic and beyond has been an auspicious phase for IPO markets.

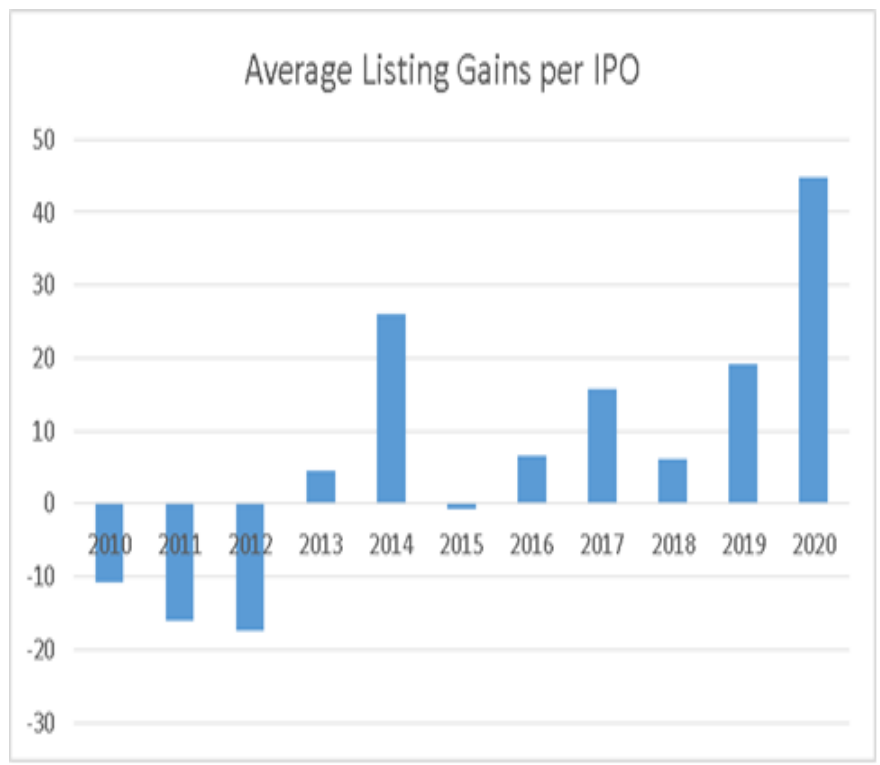

Figure 4 Average Listing Gains per IPO over the Years

For all the years, Average times subscribed in the RII category obtained by dividing sum of all times subscribed in that year 
across all IPOs by number of IPOs in that year, when plotted with the average listing gains per IPO reveal strong correlation of 0.85 as shown in figure 5. The average RII times subscribed was highest in 2020 at 21.34. The strong correlation demonstrates how mostly listing gains are driven by RII activism.

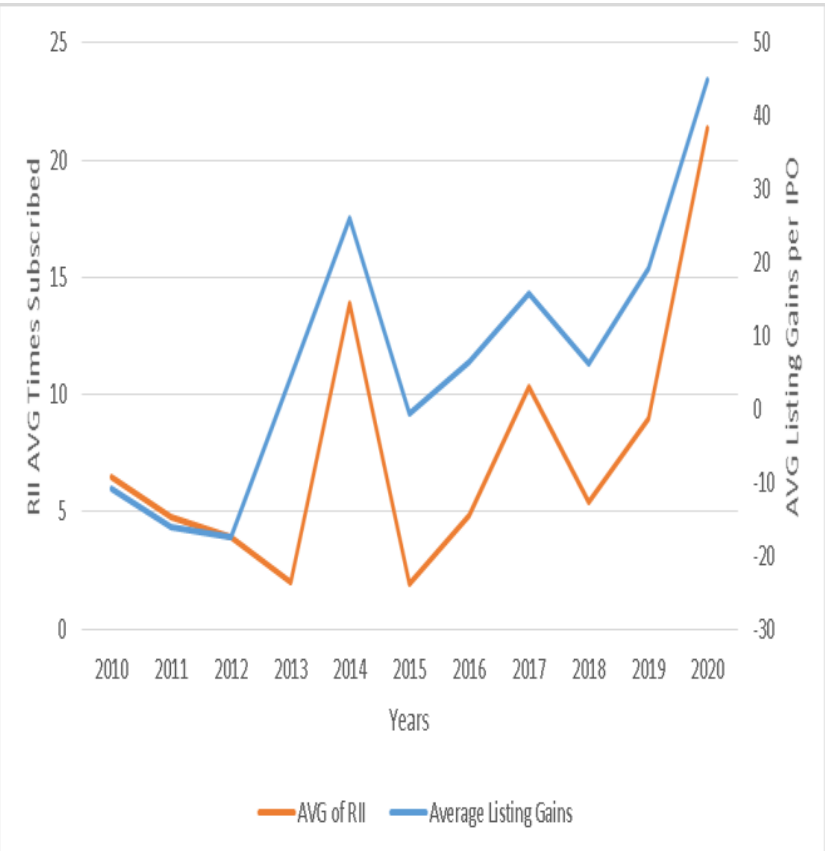

Figure 5 Average of RII Times Subscribed vis-a-vis Average Listing Gains per IPO

In addition to the above, the average issue size has also increased over the years as demonstrated by figure 6 . This shows how companies are realizing the investor behaviour and raising all the way more funds especially at a time when economic activity slowed down due to nationwide lockdown.

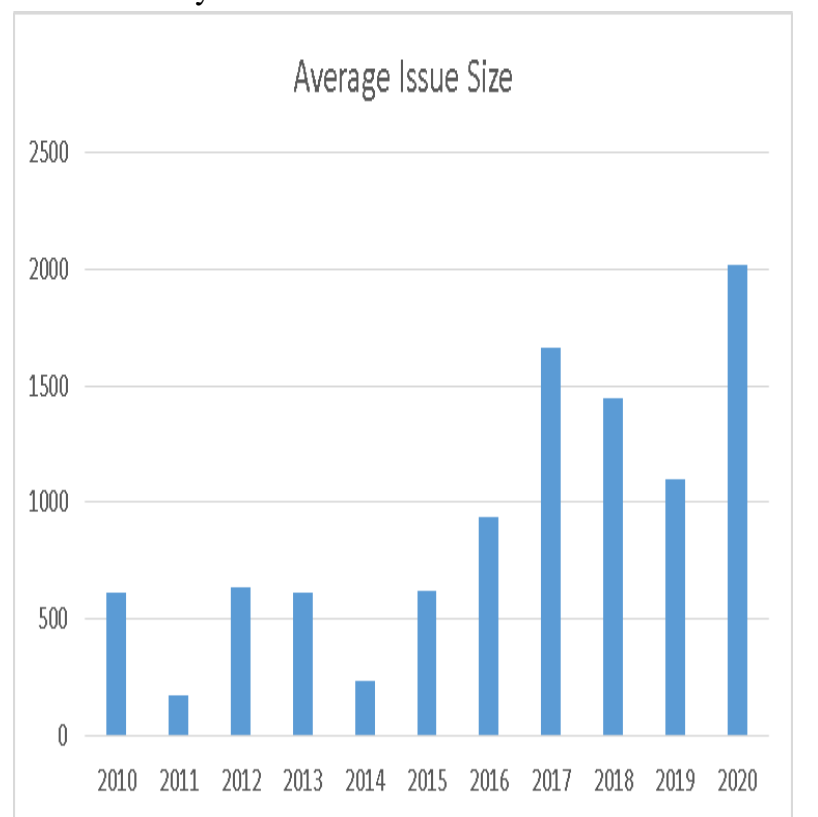

Figure 6 Average Issue Size of IPOs across years (Sourceresearcher's calculations)
Average listing gains of IPOs across the years when compared with performance of BSE Sensex (base 1978-79) (Reserve Bank of India - Handbook of Statistics on Indian Economy, n.d.) in figure 7 tells us how in 2020 listing gains far out performed the performance of the index itself. There is a possibility that to eat greater returns on listing gains, investors started pulling out funds from other stocks and started investing in IPOs. The position of the index with respect to listing gains, once the IPO frenzy subsides would substantiate the analysis presented here. To get a clearer picture a future scope of study could be to gather details of volume selling around times of IPO in the index listed stocks.

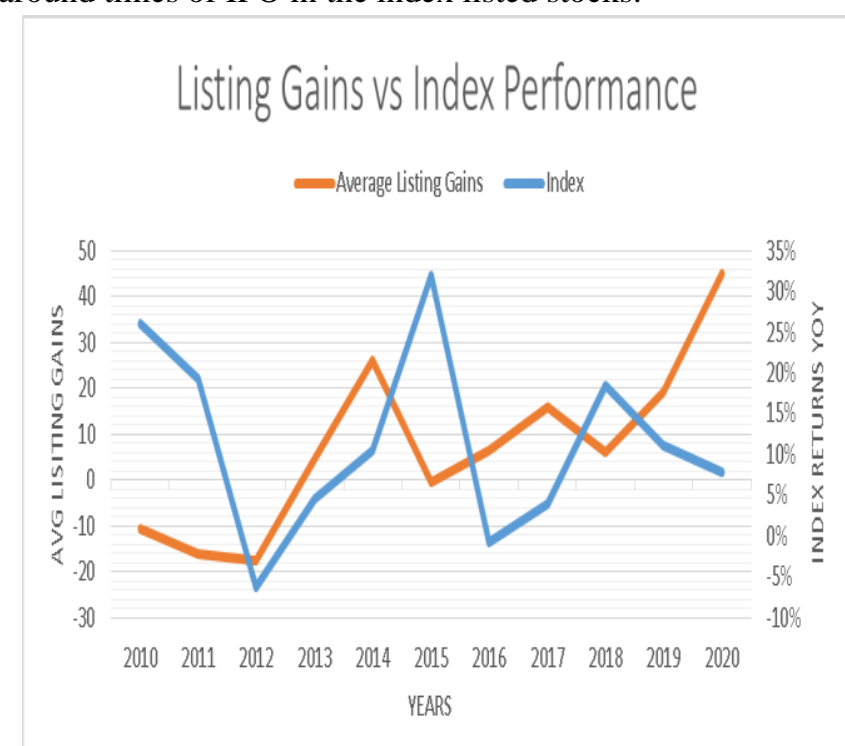

Figure 7 Listing Gains (\%) vis-a-vis BSE Sensex Performance YoY (Source- researcher's calculation and RBI Handbook on Statistics 2020)

\section{Scope for Future Research}

IPO listing data of year 2021, when the year completes will help us gather more evidence for the above-mentioned points. There is an inherent limitation in the analysis presented here. The figures and analysis thereof may not capture the over optimism of investors in entirety. An IPO when opens stays active for application for three days. The listing usually takes another seven days. By the time refunds are issued for unsuccessful applicants it takes three plus four days. Assuming successful applicants, who applied for listing gains only sell on the date of listing, it takes another two days to be allowed to withdraw the amount to the bank account as per latest SEBI guidelines. On average funds are blocked in an IPO for 7-10 days. Meanwhile, if another IPO opens, it becomes difficult for plenty of retail investors to bid owing to shortage of funds. Funds blocked in applying for one lot of any IPO are somewhat around 15,000 INR (USD 200 approximately). To better analyse the fact, we need concrete data regarding how many retail investors hold how much amount in their savings bank. Reserve bank of India publishes the region wise savings 
deposits. However, if they also publish concentration of amounts in accounts along with standard deviation of amounts in savings bank accounts, we can analyse how many investors face shortage of funds to apply in multiple IPOs simultaneously. Besides, Small and Medium Enterprises IPOs have not been considered for this study. Combining them into the study to analyse for pre and post covid would also give additional insights into investor behaviour in RII segments.

\section{Conclusion}

While I write this conclusion, fifteen IPOs have been opened so far as we are nearly 3 months into 2021. These issues have raised capital of INR 14550 Crores with an average of INR 970 crore (USD 130 Million) per issue. Year 2020 alone witnessed fourteen IPOs in all which raised INR 26245 Crores with an average of INR 1875 crores (USD 250 Million). Some major IPOs announced and upcoming for 2021 include LIC, Barbeque Nation, NSDL, etc. This goes on to show how companies are detecting activism of investors and especially retail ones and are more strategically and carefully targeting 2021 as the golden year of IPOs in the history of Indian markets. I conclude that the higher than usual listing gains and greater than usual issue size in the pandemic and beyond era is influenced by a paradigm shift in behaviour of retail investors of India as indicated by numbers above. To further corroborate the fact, a survey of retail investors in India could be insightful in future and is also subject to quality data collection. That would help us better understand the changing mindsets of Indian investors. Besides the trail of numbers, the footprints left on search engines about the search results in popularity in India in connection to the IPOs, also reveal the increasing urge to make short term gains and more and more investors are overlooking fundamentals in favour of grey market premium. To analyse this better I see text analytics-based papers in future which analyse comments on various posts and comments online which discuss grey market premiums.

\section{List of Figures and Tables}

Figure 1 Youth Unemployment over the years in India (Source- Statista)

Figure 2 Grey Market Premium Search statistics as per Google Trends

Figure 3 Grey Market Premium, IPO, Zerodha Search statistics as per Google Trends

Figure 4 Average Listing Gains per IPO over the Years

Figure 5 Average of RII Times Subscribed vis-a-vis Average Listing Gains per IPO

Figure 6 Average Issue Size of IPOs across years (Sourceresearcher's calculations)

Figure 7 Listing Gains (\%) vis-a-vis BSE Sensex Performance YoY (Source- researcher's calculation and RBI Handbook on Statistics 2020)
Table 1 Descriptive Statistics of Listing Gains (Source: researcher's calculations)

Table 2 Descriptive Statistics of Issue Size (Source: researcher's calculations)

Table 3 Descriptive Statistics of Current Gains (Source: researcher's calculations)

Table 4 Category Wise Change in Average Times Subscribed across Pre and Post Covid Times (Source- researcher's calculations)

\section{References}

[1] 10.8 Million And Counting: Take A Look At How Many Jobs Covid-19 Has Wiped Out. (n.d.). Retrieved March 18, 2021, from https://www.moneycontrol.com/news/business/econ omy/10-8-million-and-counting-take-a-look-athow-many-jobs-covid-19-has-wiped-out5704851.html

[2] Ali, M., Alam, N., \& Rizvi, S. A. R. (2020). Coronavirus (COVID-19)—An epidemic or pandemic for financial markets. Journal of Behavioral and Experimental Finance, 27, 100341. https://doi.org/10.1016/j.jbef.2020.100341

[3] Bhattacharjee, A., \& Das, J. (2020). COVID-19 and the Indian Stock Market Mayhem (SSRN Scholarly Paper ID 3616432). Social Science Research Network. https://papers.ssrn.com/abstract=3616432

[4] BSE (formerly Bombay Stock Exchange) | Market watch-Download. (n.d.). Retrieved March 2, 2021, from https://www.bseindia.com/markets/keystatics/Keyst at_maktcap.aspx

[5] Cornelli, F., Goldreich, D., \& Ljungqvist, A. (2006). Investor Sentiment and Pre-IPO Markets. The Journal of Finance, 61(3), 1187-1216. https://doi.org/10.1111/j.1540-6261.2006.00870.x

[6] Ding, D., Guan, C., Chan, C. M. L., \& Liu, W. (2020). Building stock market resilience through digital transformation: Using Google trends to analyze the impact of COVID-19 pandemic. Frontiers of Business Research in China, 14(1), 21. https://doi.org/10.1186/s11782-020-00089-z

[7] Google Trends. (n.d.). Google Trends. Retrieved March 19, 2021, from https://trends.google.com/trends/?geo=US

[8] Ibbotson, R. G., \& Ritter, J. R. (1995). Chapter 30 Initial public offerings. In Handbooks in Operations Research and Management Science (Vol. 9, pp. 993-1016). Elsevier. https://doi.org/10.1016/S09270507(05)80074-X

[9] India-Youth unemployment rate 1999-2020. (n.d.). Statista. Retrieved March 18, 2021, from 
https://www.statista.com/statistics/812106/youthunemployment-rate-in-india/

[10] Loughran, T., Ritter, J. R., \& Rydqvist, K. (1994). Initial public offerings: International insights. Pacific-Basin Finance Journal, 2(2-3), 165-199. https://doi.org/10.1016/0927-538X(94)90016-7

[11] Manu, K. S., \& Saini, C. (2020). Valuation Analysis of Initial Public Offer (IPO): The Case of India. Paradigm, 24(1), 7-21. https://doi.org/10.1177/0971890720914100

[12] Ndirangu, A., Ouma, B., \& Munyaka, F. (2014). Factors Influencing Individual Investor Behaviour During Initial Public Offers in Kenya (SSRN Scholarly Paper ID 2482358). Social Science Research Network. https://papers.ssrn.com/abstract=2482358

[13] Pollock, T. G., \& Rindova, V. P. (2003). Media Legitimation Effects in the Market for Initial Public Offerings. Academy of Management Journal, 46(5), 631-642. https://doi.org/10.5465/30040654

[14] Poornima, D. S. (2016). A STUDY ON THE PERFORMANCE OF INITIAL PUBLIC OFFERING OF COMPANIES LISTED. 6(11), 17.

[15] Reserve Bank of India-Handbook of Statistics on Indian Economy. (n.d.). Retrieved March 16, 2021, from https://www.rbi.org.in/Scripts/AnnualPublications.a spx ?head=Handbook $\% 20$ of $\% 20$ Statistics $\% 20$ on $\% 2$ OIndian\%20Economy

[16] Sahoo, S., \& Rajib, P. (2010). After Market Pricing Performance of Initial Public Offerings (IPOs): Indian IPO Market 2002-2006. Vikalpa: The Journal for Decision Makers, 35(4), 27-44. https://doi.org/10.1177/0256090920100403

[17] Sethi, M., Gupta, P., Mukherjee, S., \& Agrawal, S. (2020). Do Indian Stock Market Message Board Discussions Really Matter? A Machine Learningbased Approach. In R. Biswas \& M. Michaelides (Eds.), Research in Finance (pp. 201-216). Emerald Publishing Limited. https://doi.org/10.1108/S0196382120200000036010

[18] Singh, S. (2012). Offer Document Disclosures and its Impact on Equity Return in India. INTERNATIONAL JOURNAL OF MANAGEMENT \& INFORMATION TECHNOLOGY, 2(1), 31-45. https://doi.org/10.24297/ijmit.v2i1.1408

[19] Wu, G., Yang, B., \& Zhao, N. (2020). Herding Behavior in Chinese Stock Markets during COVID19. Emerging Markets Finance and Trade, 56(15), 3578-3587.

https://doi.org/10.1080/1540496X.2020.1855138 